DOI: https://doi.org/10.24127/ajpm.v9i2.2742

\title{
ASOSIASI KEMAMPUAN KONEKSI DAN PEMECAHAN MASALAH MATEMATIKA: CROSS-SECTIONAL DI TIMOR BARAT
}

\author{
Aloisius Loka Son ${ }^{1}$, Sudirman $^{2}$, Sri Adi Widodo ${ }^{3}$ \\ ${ }^{1}$ Universitas Timor, Kefamenanu, Indonesia \\ ${ }^{2}$ Universitas Wiralodra, Indramayu, Indonesia \\ ${ }^{3}$ Universitas Sarjanawiyata Tamansiswa, Yogyakarta, Indonesia \\ E-mail: $\quad$ elson44@ymail.com ${ }^{1)}$ \\ sudirmanunwir@gmail.com $^{2)}$ \\ sriadi@ustjogja.ac.id $^{3)}$
}

Received 07 April 2020; Received in revised form 13 June 2020; Accepted 17 June 2020

\begin{abstract}
Abstrak
Penelitian cross-sectional ini dilakukan untuk menganalisis ada tidaknya asosiasi antara kemampuan koneksi matematika (KKM) dan kemampuan pemecahan masalah matematika (KPMM), serta antara masing-masing indikator KKM dan KPMM siswa. Partisipan dalam penelitian ini adalah siswa kelas VII pada dua SMP Negeri di Kota Kefamenanu-Timor Barat-NTT tahun pelajaran 2018/2019, sebanyak 50 siswa dengan perincian 30 siswa dari sekolah A, dan 20 siswa dari sekolah B. Alat pengumpulan data yang digunakan adalah tes KKM dan tes KPMM. Teknik analisa data yang digunakan adalah uji chisquare dan uji koefisien kontingensi. Temuan hasil penelitian ini adalah terdapat asosiasi yang kuat antara KKM dan KPMM siswa, serta terdapat asosisi yang kuat antara masing-masing indikator KKM dan KPMM siswa. Karena itu, KKM dan KPMM siswa sebagai bagian integral dari mental kognitif sangat penting untuk ditekankan dalam proses dan evaluasi belajar matematika, sehingga siswa mampu melihat matematika sebagai hal yang berguna, relevan dan terintegrasi, serta mampu memecahkan berbagai masalah matematika yang dihadapi.
\end{abstract}

Kata kunci: Asosiasi; studi cross-sectional; kemampuan koneksi matematika; kemampuan pemecahan masalah matematika.

\begin{abstract}
This cross-sectional study was conducted to analyze whether there was an association between the mathematical connections ability (MCA) and the mathematical problem-solving ability (MPSA), as well as between each indicator of MCA and MPSA of students. Participants in this study were students of class VII in two State Junior High Schools in Kefamenanu city-West Timor-NTT in the academic year 2018/2019, as many as 50 students with details of 30 students from school A, and 20 students from school B. Data collection tools used were MCA tests and MPSA tests. The data analysis technique used is the chi-square test and contingency coefficient test. The findings of this study are that there is a strong association between MCA and MPSA of students, as well as there is a strong association between each MCA indicators and MPSA of the student. Thus, MCA and MPSA of students as an integral part of cognitive mental are very important to be emphasized in the mathematics learning process and evaluation, so students are able to see mathematics as a useful, relevant and integrated, as well as able to solve various mathematical problems encountered.
\end{abstract}

Keywords: Association; cross-sectional study; mathematical connections ability, mathematical problemsolving ability.

\section{PENDAHULUAN}

Kemampuan koneksi dan pemecahan masalah matematika merupakan bagian dari kemampuan kognitif yang harus dimiliki oleh siswa.
Kemampuan koneksi dan pemecahan masalah matematika sangat berpengaruh terhadap keberhasilan siswa dalam menyelesaikan masalahmasalah matematis di lingkungan 
sekolah maupun dalam kehidupan sehari-hari (Simamora, Saragih, \& Hasratuddin, 2018; Yuanita, Zulnaidi, \& Zakaria, 2018; Yumiati \& Haji, 2018). Karena itu, National Council of Teachers of Mathematics (NCTM, 2000) mengemukakan lima kemampuan utama berfikir matematis yang harus dicapai siswa dalam pembelajaran matematika yaitu kemampuan pemecahan masalah, kemampuan komunikasi, kemampuan koneksi, kemampuan penalaran dan pembuktian, dan kemampuan representasi.

Pentingnya memiliki kemampuan koneksi matematis, karena kemampuan ini menghubungkan matematika dengan dunia nyata, dengan disiplin ilmu lain dan konsep matematika lainnya (GarcíaGarcía \& Dolores-Flores, 2018). Flynn et al., (2015) mengidentifikasi komponen penting yang harus dicapai siswa dalam pembelajaran matematika seperti: 1) menghubungkan ide-ide matematika dengan konsep lain dalam matematika, dengan pengalaman seharihari, dan dengan disiplin ilmu lain, dan 2) mengembangkan dan menerapkan pengetahuan matematika baru melalui pemecahan masalah. Sejalan dengan pernyataan ini, (NCTM, 2000) mengatakan bahwa koneksi matematika adalah koneksi antara konsep matematika satu dengan lainnya, antara berbagai topik matematika, antara matematika dan bidang pengetahuan lainnya, dan antara matematika dan kehidupan sehari-hari. Berdasarkan beberapa pendapat di samping, dapat disimpulkan bahwa koneksi matematika meliputi tiga aspek yakni aspek koneksi antar topik matematika, aspek koneksi matematika dengan disiplin ilmu lain, dan aspek koneksi matematika dengan kehidupan sehari-hari.

Kemampuan matematis lainnya yang penting bagi siswa yakni kemampuan pemecahan masalah matematika. Mukasyaf, Fauzi, \& Mukhtar (2019) mengatakan bahwa kemampuan pemecahan masalah matematika adalah salah satu kemampuan terpenting yang harus dimiliki siswa untuk memproses informasi yang diberikan dalam menyelesaikan masalah. Melalui pemecahan masalah matematika, siswa dapat belajar memperdalam pemahaman mereka tentang konsep matematika dengan bekerja melalui masalah yang dipilih dengan cermat, dan menerapkan matematika untuk masalah-masalah nyata (Beigie, 2008).

Proses untuk memecahkan suatu masalah matematika membutuhkan penerapan strategi penyelesaian masalah, dan dapat mengarahkan pemecah masalah untuk mengeksplorasi banyak ide dengan mengembangkan dan menguji hipotesis (Son, Darhim, \& Fatimah, 2020). Sehubungan dengan proses pemecahan masalah, Foshay \& Kirkley (2003) menawarkan model pemecahan masalah yang umum, yang dikenal dengan Bransford's IDEAL model, yaitu: 1) identifikasi masalah (identify), 2) mendefinisikan masalah dengan memikirkan dan memilah informasi yang relevan (define), 3) mengeksplor solusi dengan melihat alternatif, brainstorming, serta memeriksa berbagai kemungkinan (explore), 4) menyelesaikannya berdasarkan strategi (act), dan 5) memeriksa kembali serta mengevaluasi proses aktivitas (look back).

Walaupun kemampuan koneksi dan pemecahan masalah matematika merupakan kemampuan yang harus dicapai dalam pembelajaran matematika, namun kedua komponen ini masih dianggap sebagai kemampuan yang sulit untuk dikuasai oleh siswa. Hal ini sesuai dengan hasil penelitian 
Kenedi, Helsa, Ariani, Zainil \& Hendri (2019) bahwa kemampuan koneksi siswa di sekolah dalam memecahkan masalah matematika masih tergolong lemah. Kemampuan koneksi matematika harus menjadi fokus perhatian karena masih banyak siswa yang melakukan kesalahan menyelesaikan soal-soal kemampuan koneksi matematika, sehingga penting untuk dicirikan sebagai dasar penelitian lebih lanjut (Arjudin, Sutawidjaja, Irawan, \& Sa'dijah, 2016).

Hasil penelitian lainnya oleh Son, Darhim, \& Fatimah (2019) mengatakan bahwa kemampuan pemecahan masalah matematika sebagian besar siswa masih tergolong rendah. Dindyal, Guan, Lam, Hoong, \& Seng (2012) mengatakan bahwa kemampuan pemecahan masalah matematika merupakan salah satu kemampuan kognitif yang sulit dipahami siswa. Memecahkan masalah matematika adalah aktivitas kognitif yang sulit dalam banyak kasus (García, Boom, Kroesbergen, Nunez, \& Rodriguez, 2019).

Banyak peneliti yang memfokuskan penelitiannya pada kemampuan koneksi dan kemampuan pemecahan masalah matematika, namun masih sedikit yang mengkaji asosiasi kemampuan koneksi dan kemampuan pemecahan masalah siswa. Penelitian-penelitian yang terkait seperti Karasel, Ayda, \& Tezer (2010) mengkaji tentang hubungan antara kecemasan matematika dan keterampilan pemecahan masalah matematika. Özcan, (2016) mengkaji hubungan antara keterampilan pemecahan masalah matematika dan kemandirian belajar. Ernaningsih \& Wicasari (2017) melakukan analisis representasi matematis, komunikasi dan koneksi matematis. Kenedi et al., (2019) mengkaji tentang koneksi matematika siswa untuk memecahkan masalah matematika, menemukan kenyataan bahwa guru kurang memperhatikan kemampuan koneksi matematika siswa dalam pembelajaran, yang merupakan bagian tak terpisahkan dari lima keterampilan dasar dalam belajar matematika.

Sejalan dengan kenyataan yang ditemukan Kenedi et al., (2019), maka dilakukan wawancara dengan beberapa guru matematika pada sekolah yang berbeda-beda di sekitar lokasi penelitian berkaitan dengan kemampuankemampuan matematis. Sebagian besar guru lebih kenal dan paham akan kemampuan pemecahan masalah dibanding kemampuan koneksi matematika. Sebagiannya lagi mengatakan paham, namun sulit menerapkannya dalam proses maupun evaluasi hasil belajar matematika.

Uraian di atas sebagai dasar penelitian ini untuk menganalisis ada tidaknya asosiasi antara kemampuan koneksi matematika (KKM) dan kemampuan pemecahan masalah matematika (KPMM), dan antara masing-masing indikator $\mathrm{KKM}$ dan KPMM siswa di Timor Barat-Indonesia.

\section{METODE PENELITIAN}

Metode penelitian yang digunakan adalah penelitian kuantitatif dengan rancangan cross-sectional design. Studi cross-sectional dapat digunakan untuk mengeksplorasi hubungan timbal balik antar variabel (Hua \& David, 2009). Hubungan timbal balik antar variabel yang dimaksudkan dalam penelitian ini adalah asosiasi antara kemampuan koneksi matematika dan kemampuan pemecahan masalah matematika siswa.

Penelitian ini dilakukan di kelas VII pada dua SMP Negeri di Kota Kefamenanu-Timor Barat-NTT tahun pelajaran 2018/2019. Dua SMP Negeri ini dipilih secara purposive sampling 
dengan alasan kedua sekolah tersebut yang pertama kalinya menggunakan Kurikulum 2013 untuk tingkat sekolah menengah pertama di kabupaten Timor Tengah Utara. Partisipan dalam penelitian ini sebanyak 50 siswa dengan perincian 30 siswa dari sekolah $\mathrm{A}$, dan 20 siswa dari sekolah B.

Instrumen yang digunakan untuk memperoleh data dalam penelitian ini adalah tes KKM dan tes KPMM. Tes KKM dalam bentuk uraian yang terdiri dari 5 nomor, sedangkan tes KPMM juga dalam bentuk uraian terdiri dari 4 nomor. Penyusunan soal tes KKM dan KPMM melalui proses validasi ahli, dan selanjutnya diujicobakan kepada siswa untuk mengetahui tingkat validitas dan reliabilitasnya. Rata-rata hasil penilaian validator terhadap soal KKM sebesar 93,33, sedangkan rata-rata hasil penilaian validator terhadap soal KPMM sebesar 91,67 yang masingmasing menunjukkan bahwa soal tes tersebut dalam kategori baik dan dapat digunakan pada tahap selanjutnya. Sedangkan hasil ujicoba terhadap 19 orang siswa diperoleh nilai alpha cronbach untuk soal tes KKM sebesar 0.88, dan untuk soal tes KPMM sebesar 0.69 yang berarti butir soal tes KKM dan KPMM tersebut adalah reliabel. Nilai pearson correlation dari kelima soal tes KKM secara berturut-turut adalah 0,$89 ; 0,62 ; 0,93 ; 0,89$; dan 0,82 . Sedangkan nilai pearson correlation dari keempat soal tes KPMM secara berturut-turut adalah 0,$73 ; 0,75 ; 0,65$; dan 0,79 . Hasil uji validitas butir soal ini menunjukkan bahwa kelima soal tes KKM dan keempat soal tes KPMM adalah valid.

Teknik analisa data yang digunakan adalah chi-square tests dan uji koefisien kontingensi. Chi-square tests digunakan untuk mengetahui signifikan tidaknya asosiasi antara KKM dan KPMM siswa. Sedangkan uji koefisien kontingensi untuk mengetahui kuat tidaknya asosiasi antara KKM dan KPMM siswa. Chi-square test maupun uji koefisien kontingensi diuji menggunakan IBM SPSS Statistics 22.

\section{HASIL DAN PEMBAHASAN}

Asosiasi Kemampuan Koneksi dan Pemecahan Masalah Matematika

Kualifikasi kemampuan koneksi matematika (KKM) dan kemampuan pemecahan masalah matematika (KPMM) siswa dapat disajikan dalam Tabel 1.

Tabel 1. Krosstabulasi KKM*KPMM siswa.

\begin{tabular}{cccccc}
\hline & & \multicolumn{3}{c}{ KPMM } & \multirow{2}{*}{ Total } \\
\cline { 3 - 5 } & & Rendah & Sedang & Tinggi & \\
\hline \multirow{3}{*}{ KKM } & Rendah & 4 & 2 & 0 & 6 \\
& Sedang & 4 & 24 & 5 & 33 \\
& Tinggi & 0 & 6 & 5 & 11 \\
& Total & 8 & 32 & 10 & 50 \\
\hline
\end{tabular}

Tabel 1 menunjukkan bahwa terdapat empat siswa yang memiliki KKM dan KPMM dalam kategori rendah. Dua siswa memiliki KKM rendah dan KPMM sedang, tidak ada siswa yang memiliki KKM rendah dan KPMM tinggi. Empat siswa memiliki
KKM sedang dan KPMM rendah. Dua puluh empat siswa memiliki KKM dan KPMM dalam kategori sedang. Lima siswa memiliki KKM sedang dan KPMM tinggi, tidak ada siswa yang memiliki KKM tinggi dan KPMM rendah. Enam siswa memiliki KKM 
DOI: https://doi.org/10.24127/ajpm.v9i2.2742

tinggi dan KPMM sedang serta lima siswa memiliki KKM dan KPMM tinggi.
Signifikannya asosiasi antara KKM dan KPMM siswa dianalisa menggunakan chi-square tests yang hasilnya dapat disajikan dalam Tabel 2.

Table 2. Hasil uji asosiasi antara KKM dan KPMM siswa.

\begin{tabular}{lccc}
\hline & Value & df & Asymp. sig. (2-sided) \\
\hline Pearson chi-square & $18.277^{\mathrm{a}}$ & 4 & 0.001 \\
Nof valid cases & 50 & & \\
\hline
\end{tabular}

Tabel 2 menunjukkan bahwa nilai pearson chi-square sebesar 18.277 dan asymp. sig. sebesar 0,001<0,05 sehingga disimpulkan bahwa terdapat asosiasi yang signifikan antara kemampuan koneksi matematika dan kemampuan pemecahan masalah matematika siswa. Besarnya asosiasi antara kemampuan koneksi matematika dan kemampuan pemecahan masalah matematika dapat dianalisa menggunakan uji koefisien kontingensi, yang hasilnya dapat disajikan pada Tabel 3.

Tabel 3. Hasil uji koefisien kontingensi KKM dan KPMM siswa.

\begin{tabular}{lccc}
\hline & & Value & Approx. sig. \\
\hline Nominal by nominal & Contingency coefficient & 0.517 & 0.001 \\
\hline Nof Valid Cases & & 50 & \\
\hline
\end{tabular}

Tabel 3 menunjukkan bahwa nilai koefisien kontingensi sebesar 0.517 . Value ini merupakan besarnya asosiasi antara kemampuan koneksi dan kemampuan pemecahan masalah matematika siswa. Kuat tidaknya asosiasi antara KKM dan KPMM dapat diketahui dengan membandingkan nilai koefisien kontingensi (C) dengan nilai C maksimal yakni $C_{\text {maks }}=$ $\sqrt{\frac{3-1}{3}}=\sqrt{\frac{2}{3}}=0.816 . \quad 3$ merupakan banyaknya kolom atau baris minimal, sehingga $\quad C_{\text {maks }}-C=0.816-$ $0.517=0,299$. Nilai $C_{\text {maks }}-C<C$ maka asosiasi antara kemampuan koneksi matematika dan kemampuan pemecahan masalah matematika dalam kategori kuat. Jadi, dapat disimpulkan bahwa terdapat asosiasi yang kuat antara kemampuan koneksi matematika dan kemampuan pemecahan masalah matematika siswa.

Selain menganalisis asosiasi antara kemampuan koneksi matematika dan kemampuan pemecahan masalah matematika, dapat dianalisa juga asosiasi antara masing-masing indikator kemampuan koneksi matematika dan kemampuan pemecahan masalah yang dapat diuraiakn pada bagian berikut.

\section{Asosiasi Antara Indikator-Indikator kemampuan Koneksi dan Pemecahan Masalah Matematika \\ Indikator-indikator kemampuan} koneksi matematika yang digunakan adalah (1) memahami representasi ekuivalen dari konsep yang sama (indikator KKM I). (2) Memahami hubungan prosedur matematika suatu representasi ke prosedur representasi yang ekuivalen (indikator KKM II). (3). Menggunakan keterkaitan antar topik 
matematika dengan topik lain dalam matematika (indikator KKM III). (4) Menggunakan keterkaitan antara topik matematika dengan topik lain di luar matematika (indikator KKM IV), dan (5) Menggunakan matematika dalam kehidupan sehari-hari (indikator KKM V).

Kualifikasi indikator-indikator KKM dan KPMM siswa dapat disajikan dalam Tabel 4.

Tabel 4. Krostabulasi indikator-indikator KKM*KPMM siswa.

\begin{tabular}{llcccc}
\hline & & & KPMM & \multirow{2}{*}{ Total } \\
\cline { 3 - 5 } Indikator KKM I & Rendah & Sedang & Tinggi & \\
& Rendah & 3 & 1 & 0 & 4 \\
& Sedang & 3 & 19 & 6 & 28 \\
& Tinggi & 2 & 12 & 4 & 18 \\
Indikator KKM II & Rendah & 4 & 4 & 0 & 8 \\
& Sedang & 4 & 21 & 6 & 31 \\
& Tinggi & 0 & 7 & 4 & 11 \\
Indikator KKM III & Rendah & 5 & 6 & 0 & 11 \\
& Sedang & 2 & 11 & 2 & 15 \\
Indikator KKM IV & Tinggi & 1 & 15 & 8 & 24 \\
& Rendah & 6 & 6 & 1 & 13 \\
Indikator KKM V & Sedang & 2 & 14 & 3 & 19 \\
& Tinggi & 0 & 12 & 6 & 18 \\
& Rendah & 4 & 6 & 1 & 11 \\
& Sedang & 4 & 23 & 5 & 32 \\
& Tinggi & 0 & 3 & 4 & 7 \\
\hline
\end{tabular}

Signifikannya asosiasi antara indikator-indikator KKM dan KPMM dianalisa menggunakan chi-square tests, yang hasilnya disajikan pada Tabel 5 .

Tabel 5. Hasil uji asosiasi antara indikator-indikator KKM dan KPMM siswa.

\begin{tabular}{lcccc}
\hline \multicolumn{1}{c}{ Source } & $\begin{array}{c}\text { Value of pearson } \\
\text { chi-square }\end{array}$ & $\begin{array}{c}\text { N of valid } \\
\text { cases }\end{array}$ & df & $\begin{array}{c}\text { Asymp. sig. } \\
\text { (2-sided) }\end{array}$ \\
\hline Indikator KKM I dan KPMM & $11.369^{\mathrm{a}}$ & 50 & 4 & .023 \\
Indikator KKM II dan KPMM & $11.118^{\mathrm{a}}$ & 50 & 4 & .025 \\
Indikator KKM III dan KPMM & $13.165^{\mathrm{a}}$ & 50 & 4 & .010 \\
Indikator KKM IV dan KPMM & $14.322^{\mathrm{a}}$ & 50 & 4 & .006 \\
Indikator KKM V dan KPMM & $10.958^{\mathrm{a}}$ & 50 & 4 & .027 \\
\hline
\end{tabular}

Tabel 5 menunjukkan bahwa besarnya asymp. sig. untuk semua indikator KKM dari indikator I hingga indikator V semuanya kurang dari 0,05, sehingga disimpulkan bahwa pada $\alpha=0.05$ :
1. Terdapat asosiasi yang signifikan antara indikator memahami representasi equivalen dari konsep yang sama dan kemampuan pemecahan masalah matematika siswa. 
2. Terdapat asosiasi yang signifikan antara indikator memahami hubungan prosedur matematika suatu representasi ke prosedur representasi yang ekuivalen dan kemampuan pemecahan masalah matematika siswa.

3. Terdapat asosiasi yang signifikan antara indikator menggunakan keterkaitan antar topik matematika dengan topik lain dalam matematika dan kemampuan pemecahan masalah matematika siswa.

4. Terdapat asosiasi yang signifikan antara indikator menggunakan keterkaitan antara topik matematika dengan topik lain di luar matematika dan kemampuan pemecahan masalah matematika siswa.

5. Terdapat asosiasi yang signifikan antara indikator menggunakan matematika dalam kehidupan sehari-hari dan kemampuan pemecahan masalah matematika siswa.

Besarnya asosiasi antara indikator-indikator kemampuan koneksi matematika dan kemampuan pemecahan masalah matematika dapat dianalisa menggunakan uji koefisien kontingensi, yang hasilnya dapat disajikan pada Tabel 6 .

Tabel 6. Hasil tes koefisien kontingensi indikator-indikator KKM dan KPMM siswa.

\begin{tabular}{|c|c|c|c|c|}
\hline \multirow{2}{*}{ Data } & \multirow{2}{*}{ Source } & \multirow{2}{*}{$\begin{array}{l}\text { Nof valid } \\
\text { cases }\end{array}$} & \multicolumn{2}{|c|}{ Contingency coefficient } \\
\hline & & & Value & Approx. sig \\
\hline \multirow{5}{*}{$\begin{array}{l}\text { Nominal } \\
\text { by } \\
\text { nominal }\end{array}$} & Indikator KKM I dan KPMM & 50 & 0.430 & 0.023 \\
\hline & Indikator KKM II dan KPMM & 50 & 0.427 & 0.025 \\
\hline & Indikator KKM III dan KPMM & 50 & 0.457 & 0.010 \\
\hline & Indikator KKM IV dan KPMM & 50 & 0.472 & 0.006 \\
\hline & Indikator KKM V dan KPMM & 50 & 0.424 & 0.027 \\
\hline
\end{tabular}

Besarnya asosiasi antara masing-masing indikator KKM dan KPMM dapat dilihat pada kolom value contingency coefficient, yang menunjukkan bahwa (1) Besarnya asosiasi antara indikator memahami representasi ekuivalen dari konsep yang sama dan kemampuan pemecahan masalah matematika siswa sebesar 0,430. (2) Besarnya asosiasi antara indikator memahami hubungan prosedur matematika suatu representasi ke prosedur representasi yang ekuivalen dan kemampuan pemecahan masalah matematika siswa sebesar 0,427. (3) Besarnya asosiasi antara indikator menggunakan keterkaitan antar topik matematika dengan topik lain dalam matematika dan kemampuan pemecahan masalah matematika siswa sebesar 0,457. (4) Besarnya asosiasi antara indikator menggunakan keterkaitan antara topik matematika dengan topik lain di luar matematika dan kemampuan pemecahan masalah matematika siswa sebesar 0,472. (5) Besarnya asosiasi antara indikator menggunakan matematika dalam kehidupan sehari-hari dan kemampuan pemecahan masalah matematika siswa sebesar 0,424.

Kuat tidaknya asosiasi antara masing-masing indikator KKM dan KPMM, dapat ditentukan dengan mengkonsultasikan nilai koefisien kontingensi dengan $C_{\text {maksimum, }}$ yag dapat disajikan dalam Tabel 7. 
DOI: https://doi.org/10.24127/ajpm.v9i2.2742

Table 7. Kekuatan asosiasi indikator-indikator KKM dan KPMM siswa.

\begin{tabular}{lcccc}
\hline \multicolumn{1}{c}{ Source } & $\mathbf{C}$ & $\boldsymbol{C}_{\text {maks }}$ & $\boldsymbol{C}_{\boldsymbol{m a k s}}-\boldsymbol{C}$ & $\begin{array}{c}\text { Perbandingan } \\
\boldsymbol{C}_{\boldsymbol{m a k s}}-\boldsymbol{C} \text { dengan C }\end{array}$ \\
\hline Indikator KKM I dan KPMM & 0,430 & 0,816 & 0,388 & $0,388<0,430$ \\
Indikator KKM II dan KPMM & 0,427 & 0,816 & 0,389 & $0,389<0,427$ \\
Indikator KKM III dan KPMM & 0,457 & 0,816 & 0,359 & $0,359<0,457$ \\
Indikator KKM IV dan KPMM & 0,472 & 0,816 & 0,344 & $0,344<0,472$ \\
Indikator KKM V dan KPMM & 0,424 & 0,816 & 0,392 & $0,392<0,424$ \\
\hline C : koefisien kontingensi & \multicolumn{5}{c}{} \\
$C_{\text {maks }}:$ Koefisien kontingensi maksimum $=\sqrt{\frac{m-1}{m}}$; m adalah banyaknya baris atau kolom minimal
\end{tabular}

Perbandingan $C_{\text {maks }}-C$ dengan $\mathrm{C}$ untuk semua indikator KKM dan KPMM pada Tabel 7 di atas adalah $C_{\text {maks }}-C<C$, yang berarti asosiasi antara masing-masing indikator $\mathrm{KKM}$ dan KPMM dalam kategori kuat, yang dirincikan sebagai berikut:

1. Terdapat asosiasi yang kuat antara indikator memahami representasi ekuivalen dari konsep yang sama dan kemampuan pemecahan masalah matematika siswa.

2. Terdapat asosiasi yang kuat antara indikator memahami hubungan prosedur matematika suatu representasi ke prosedur representasi yang ekuivalen dan kemampuan pemecahan masalah matematika siswa.

3. Terdapat asosiasi yang kuat antara indikator menggunakan keterkaitan antar topik matematika dengan topik lain dalam matematika dan kemampuan pemecahan masalah matematika siswa.

4. Terdapat asosiasi yang kuat antara indikator menggunakan keterkaitan antara topik matematika dengan topik lain di luar matematika dan kemampuan pemecahan masalah matematika siswa.

5. Terdapat asosiasi yang kuat antara indikator menggunakan matematika dalam kehidupan sehari-hari dan kemampuan pemecahan masalah matematika siswa.

Temuan yang diperoleh dalam penelitian ini adalah terdapat asosiasi yang kuat antara koneksi matematika dan kemampuan pemecahan masalah matematika. Temuan penelitian ini sejalan dengan hasil penelitian oleh Hidayat (2014) bahwa ada tingkat asosiasi yang cukup kuat antara kemampuan pemecahan masalah dan kemampuan koneksi matematika siswa. Asosiasi yang kuat antara kemampuan koneksi matematika dan kemampuan pemecahan masalah matematika mengandung makna bahwa siswa yang memiliki kemampuan koneksi matematika tinggi akan memiliki kemampuan pemecahan masalah matematika yang tinggi, atau sebaliknya jika siswa yang memiliki kemampuan pemecahan masalah matematika yang tinggi akan memiliki kemampuan koneksi matematika yang tinggi. Impilikasi ini berlaku secara linear juga pada kemampuan koneksi matematika siswa yang sedang dengan kemampuan pemecahan masalah matematika yang sedang, serta kemampuan koneksi matematika siswa yang rendah dengan kemampuan pemecahan masalah matematika yang rendah.

Sejalan juga dengan hasil analisis teori yang dilakukan oleh Kenedi et al., (2019) menegaskan 
bahwa kemampuan koneksi matematika memiliki hubungan dalam memecahkan masalah matematika. Koneksi matematika dapat meningkatkan keterampilan berpikir dalam menyelesaikan masalah matematika. Jika siswa mampu menghubungkan konsep matematika dengan konsep lain, dengan disiplin ilmu lain, bahkan dengan masalah dalam kehidupan sehari hari akan mampu memecahkan masalah matematika ataupun sebaliknya. NCTM (2000) menyarankan bahwa dengan menekankan koneksi matematika maka guru telah membantu siswa untuk menyelesaikan masalah matematika karena masalah matematika tidak terlepas dari koneksi matematika dengan konsep lain, dengan disiplin ilmu lain, dan dengan masalah dalam kehidupan sehari-hari. Pernyataan NCTM di atas mengandung makna bahwa kemampuan memecahakna masalah tidak terlepas dari kemampuan koneksi matematika. Konsekuensinya adalah kemampuan koneksi matematika memberikan efek terhadap kemampuan pemecahan masalah matematika siswa. Suharto \& Widada (2019) mengatakan bahwa ada efek langsung yang positif dari kemampuanan koneksi matematika pada kemampuan pemecahan masalah matematika.

Temuan lain dalam penelitian ini adalah terdapat asosiasi yang kuat antara indikator-indikator kemampuan koneksi matematika dengan kemampuan pemecahan masalah matematika. Indikator kemampuan koneksi matematika merepresentasi koneksi antar konsep matematika, koneksi antara konsep matematika dengan disiplin ilmu lain, dan koneksi antara konsep matematika dengan masalah dalam kehidupan sehari-hari. Jika siswa mampu menggunakan konsep matematika dalam menyelesaikan masalah dalam disiplin ilmu lain, dan masalah yang berkaitan dengan kehidupan sehari-hari maka akan mampu memecahkan masalah matematika atau sebaliknya. Namun jika siswa tidak mampu menggunakan konsep matematika dalam menyelesaikan masalah dalam disiplin ilmu lain, dan yang berkaitan dengan kehidupan sehari-hari maka akan mengalami kesulitan dalam memecahkan masalah matematika atau sebaliknya.

Merujuk pada temuan hasil penelitian ini, maka pembelajaran matematika di sekolah harus memfasilitasi siswa agar mampu memahami dan menerapkan konsep matematika dalam menyelesaikan masalah-masalah dalam matematika, dalam hubungannya dengan disiplin ilmu lain, dan yang berkaitan dengan kehidupan sehari-hari. Guru matematika harus memiliki kemampuan memfasilitasi siswa dengan kemampuan-kemampuan matematis di atas, baik dalam proses pembelajaran maupun dalam evaluasi hasil belajar matematika. Hal ini selain dapat mengembangkan kemampuan koneksi dan pemecahan masalah matematika siswa, sangat penting juga sebagai proses pengembangan minat matematika siswa (Arthur, Owusu, Asiedu-Addo, \& Arhin, 2018., Rellensmann \& Schukajlow, 2017)

\section{KESIMPULAN DAN SARAN}

Temuan penelitian adalah terdapat asosiasi yang kuat antara kemampuan koneksi matematika dan kemampuan pemecahan masalah matematika siswa. Ditinjau dari asosiasi antara masing-masing indikator kemampuan koneksi matematika dan kemampuan pemecahan masalah matematika siswa dapat disimpulkan 
bahaw 1) terdapat asosiasi yang kuat antara indikator memahami representasi ekuivalen dari konsep yang sama dan kemampuan pemecahan masalah matematika siswa. (2) Terdapat asosiasi yang kuat antara indikator memahami hubungan prosedur matematika suatu representasi ke prosedur representasi yang ekuivalen dan kemampuan pemecahan masalah matematika siswa.

(3) Terdapat asosiasi yang kuat antara indikator menggunakan keterkaitan antar topik matematika dengan topik lain dalam matematika dan kemampuan pemecahan masalah matematika siswa. (4) Terdapat asosiasi yang kuat antara indikator menggunakan keterkaitan antara topik matematika dengan topik lain di luar matematika dan kemampuan pemecahan masalah matematika siswa, dan (5) Terdapat asosiasi yang kuat antara indikator menggunakan matematika dalam kehidupan seharihari dan kemampuan pemecahan masalah matematika siswa.

Kemampuan koneksi matematika siswa adalah kemampuan siswa memahami hubungan antar konsep matematika, memahami dan menerapkan hubungan antara konsep matematika dengan disiplin ilmu lain, serta memahami dan menerapkan hubungan antar konsep matematika dengan fenomena dunia nyata. Sedangkan kemampuan pemecahan masalah matematika siswa adalah kemampuan siswa dalam menerapkan keterampilan matematika mereka dengan cara baru; mengembangkan pemahaman yang lebih mendalam tentang ide-ide matematika, dan memecakan masalah-masalah matematika yang kompleks dan tidak rutin. Karena itu, kemampuan koneksi matematika dan kemampuan pemecahan masalah matematika siswa sangat penting untuk ditekankan dalam proses dan evaluasi hasil belajar matematika, sehingga siswa mampu melihat matematika sebagai hal yang berguna, relevan dan terintegrasi, serta mampu memecahkan berbagai masalah matematika yang dihadapi. Disarankan juga agar kemampuan koneksi dan pemecahan masalah matematika siswa menjadi fokus perhatian dan penting untuk dicirikan sebagai dasar penelitian lebih lanjut.

\section{DAFTAR PUSTAKA}

Arjudin, Sutawidjaja, A., Irawan, E. B., \& Sa'dijah, C. (2016). Characterization of Mathematical Connection Errors in Derivative Problem Solving. IOSR Journal of Research \& Method in Education, 6(5), 7-12. https://doi.org/10.9790 /7388-0605050712

Arthur, Y. D., Owusu, E. K., AsieduAddo, S., \& Arhin, A. K. (2018). Connecting Mathematics to Real Life Problems: A Teaching Quality That Improves Student $\mathrm{s}$, Mathematics Interest. IOSR Journal of Research \& Method in Education, 8(4), 65-71. https://doi.org/10.9790/73880804026571

Beigie, D. (2008). Integrating Content to Create Problem-Solving Opportunities. Mathematics Teaching in the Middle School, 13(6), 352-360.

Dindyal, J., Guan, T. E., Lam, T. T., Hoong, L. Y., \& Seng, Q. K. (2012). Mathematical Problem Solving for Everyone: A New Beginning. The Mathematics Educator, 13(2), 1-20.

Ernaningsih, Z., \& Wicasari, B. (2017). Analysis of Mathematical Representation, Communication 
and Connection in Trigonometry. The 2017 International Conference on Research in Education, 45-57.

Flynn, J. K., \& et al. (2015). Mathematics 8 Curriculum Guide 2015 (First edit; J. K. Flynn, ed.). Canada: Newfoundland Labrador.

Foshay, R., \& Kirkley, J. (2003). Principles for Teaching Problem Solving. Plato Learning, 1-16. https://doi.org/10.1.1.117.8503\&re $\mathrm{p}=$ rep1\&type $=$ pdf

García-García, J., \& Dolores-Flores, C. (2018). Intra-Mathematical Connections Made by High School Students in Performing Calculus Tasks. International Journal of Mathematical Education in Science and Technology, 49(2), 227-252. https://doi.org/10.1080/0020739X.2 017.1355994

García, T., Boom, J., Kroesbergen, E. H., Nunez, J. C., \& Rodriguez, C. (2019). Planning, Execution, and Revision in Mathematics Problem Solving: Does the Order of the Phases Matter? Studies in Educational Evaluation, 83-93. https://doi.org/10.1016/j.stueduc.20 19.03.001

Hidayat, W. (2014). The Implementation Of MEAs Intruction To Students' Mathematics Problem Solving And Connecting Ability. Proceeding of International Conference On Research, Implementation And Education Of Mathematics And Sciences 2014, 18-20. Yogyakarta.

Hua, Z., \& David, A. (2009). Study Design: Cross-sectional, Longitudinal, Case, and Group. In L. Wei \& M. G. Moyer (Eds.), The Blackwell Guide to Research
Methods in Bilingualism and Multilingualism (First, p. 641). https://doi.org/10.1017/s027226310 9990052

Karasel, N., Ayda, O., \& Tezer, M. (2010). The Relationship Between Mathematics Anxiety and Mathematical Problem Solving Skills Among Primary School Students. Procedia - Social and Behavioral Sciences, 2(2), 58045807. https://doi.org/10.1016/j. sbspro.2010.03.946

Kenedi, A. K., Helsa, Y., Ariani, Y., Zainil, M., \& Hendri, S. (2019). Mathematical Connection of Elementary School Students to Solve Mathematical Problems. Journal on Mathematics Education, 10(1), 69-79. https://doi.org /10.22342/jme.10.1.5416.69-80

Mukasyaf, F., Fauzi, K. M. A., \& Mukhtar, M. (2019). Building Learning Trajectory Mathematical Problem Solving Ability in Circle Tangent Topic by Applying Metacognition Approach. International Education Studies, 12(2), 109. https://doi.org/10.5539 /ies.v12n2p109

NCTM. (2000). Principles and Standards for School Mathematics. United States of America: NCTM.

Özcan, Z. Ç. (2016). The Relationship Between Mathematical ProblemSolving Skills and Self-Regulated Learning Through Homework Behaviours, Motivation, and Metacognition. International Journal of Mathematical Education in Science and Technology, 47(3), 408-420. https://doi.org/10.1080 /0020739X.2015.1080313 
Rellensmann, J., \& Schukajlow, S. (2017). Does Students' Interest in A Mathematical Problem Depend on the Problem's Connection to Reality? An analysis of Students' Interest and Pre-Service Teachers' Judgments of Students' Interest in Problems With and Without a Connection to Reality. ZDM Mathematics Education, 49(3), 367-378. https://doi.org/10.1007 /s11858-016-0819-3

Simamora, R. E., Saragih, S., \& Hasratuddin, H. (2018). Improving Students' Mathematical Problem Solving Ability and Self-Efficacy through Guided Discovery Learning in Local Culture Context. International Electronic Journal of Mathematics Education, 14(1), 6172. https://doi.org/10.12973/iejme 13966

Son, A. L., Darhim, \& Fatimah, S. (2019). An Analysis to Student Errors of Algebraic Problem Solving Based on Polya and Newman Theory. International Seminar on Applied Mathematics and Mathematics Education, 1315(1), 012069. https://doi.org/10.1088/17426596/1315/1/012069

Son, A. L., Darhim, \& Fatimah, S. (2020). Students' Mathematical Problem-Solving Ability Based on Teaching Models Intervention and Cognitive Style. Journal on Mathematics Education, 11(2), 209-222. https://doi.org/10.22342 /jme.11.2.10744.209-222

Suharto, \& Widada, W. (2019). The Contribution of Mathematical Connection and Mathematical Communication to Problem Solving Ability. International 